\title{
A COMPACT AND PORTABLE DESIGN DEVELOPMENT OF A LOW ROLLING RESISTANCE TEST RIG
}

\author{
Greg Wheatley \\ College of Science and Engineering, James Cook University, Townsville QLD 4810, Australia, \\ greg.wheatley@jcu.edu.au (corresponding author) \\ Ashley Rains \\ College of Science and Engineering, James Cook University, Townsville QLD 4810, Australia, \\ ashley.rains@my.jcu.edu.au
}

Mohammad Zaeimi

Department of Mechanics, Mathematics and Management, Polytechnic University of Bari, Bari 70126, Italy, mohammad.zaeimi@poliba.it

Keywords: low rolling resistance, conveyor system, test rig

Abstract: Low Rolling Resistance (LRR) conveyor systems are generally preferred over traditional conveyors because of better overall efficiency lesser energy consumption required to operate. In this work, the design development and analysis path in the process of downscaling the size of an existent LRR test rig to a compact, portable and desktop-sized model is presented. Simulation has been developed using SolidWorks and finite element analysis is conducted using ANSYS to obtain the deformation, stress and strain of each part of the new design.

\section{Introduction}

A conveyor's primary function is to provide transport to bulk solids/materials across a vast distance; usually linear in geometry with the exception of inclines and declines, depending on application. In the manufacturing industry, conveyor belts are designed to move products from one point to another or through a chain of assembly. Due to the increase in goods and services, conveyors are becoming an increasing interest for many large-scale industries. These conveyors are most commonly seen in airport baggage claims, mining industries, and escalators [1].

In essence, a conveyor belt is simply an endless strap of flexible material stretched between two drums and supported at intervals by idler rollers. As industries commonly use conveyors to transport bulk materials across a vast distance, it is imperative to ensure the belt cover is regularly monitored for damage as well as reducing the overall cost of operating the system; as with extended usage, the possibility of damage and cost to function increases accordingly. The indentation rolling resistance of conveyor belts is an important design consideration for long belt conveyors and can also be important for heavily loaded belt conveyors [2]. Indentation rolling resistance occurs due to the deformation of the conveyor belt bottom cover as it is squeezed between the carcass and successive idler rolls. The bottom cover is compressed as the belt drives into the roll, and then recovers as the belt travels over the roll compressed due to the viscoelastic (timedependent) properties of the rubber, an asymmetric pressure distribution forms, resulting in indentation rolling resistance [3]. It is dependent on the properties of the conveyor belt including the carcass and bottom cover as well as properties of the belt conveyor including induced loads, belt speed, and ambient temperature and idler roll diameter [2].

From the previous studies which have been focused on the components of energy loss of trough conveyors, it can be found that the idler indentation rolling resistance can account for approximately $60 \%$ of the total rolling resistance $[4,5]$. Therefore, reducing the indentation rolling resistance is an effective way to decrease the overall power consumption and the belt tension.

The aim of designing Low Rolling Resistance (LRR) conveyor systems is to reduce the rolling resistance of the conveyor belt; thereby increasing the overall efficiency and decreasing energy consumption required to operate. There are a multitude of reasons as to why LRR conveyors are typically preferred over conventional conveyors. The most salient feature is due to the fact that the belt reduces the rubber hysteresis losses of the running cover compounds. The LRR belt has a modified bottom cover rubber with less hysteresis energy loss, compared to the conventional belt bottom cover rubber.

The design of an LRR conveyor testing rig will be largely influenced by the resources available as conveyors are renowned for their vast lengths in transporting goods and materials. However, the primary objective of this work is to minimize space taken and downscale the existent LRR test rig situated in the University of Newcastle to a compact, portable and desktop-sized model. This report will highlight the development and analysis path undertaken in the construction of the proposed design.

The rest of this paper is organized as follows. In Section 2 , key considerations for designing and analyzing of the new test rig design are proposed. Section 3 details the design development and numerical results. Finally, conclusions are presented in Section 4. 


\section{Methodology}

\subsection{Existing test rig}

As shown in figure 1 , the test facility is classified as a "two pulley test machine" by CEMA (Conveyor Equipment Manufacturers Association) and is designed to accept both fabric and steel cord belts and test over a range of typical operating parameters and conditions.

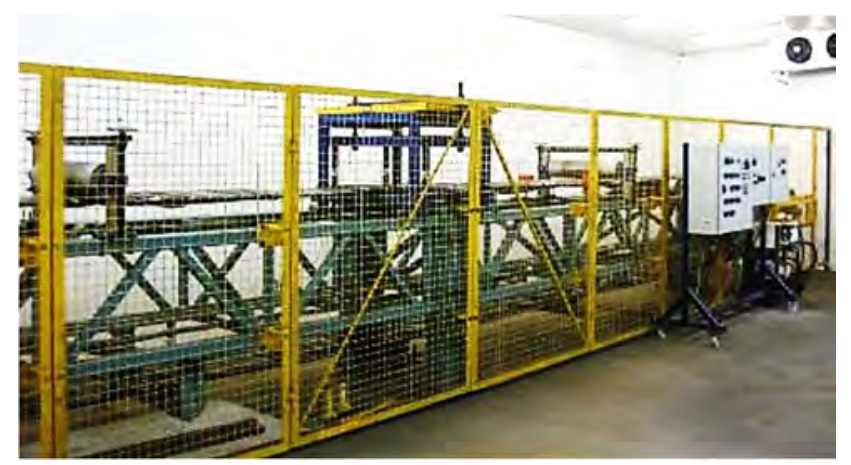

Figure 1 Rolling resistance test facility [2]

Figure 1 shows the undulating conveyor belt path that is created by the hold-down rolls. These two rolls are equally spaced on either side of the test idler roll and are arranged such that they push the belt down and hence apply a load to the test idler roll. The use of this type of loading method was first proposed by Spaans [6] and is designed to simulate actual belt operating conditions. Primarily the loading mechanism is designed to transfer the load to the test idler roll through the belt carcass in the same manner that the belt and bulk material weight that is suspended between successive idler sets is transferred through the carcass. This loading method also simulates the conveyor belt sag that occurs between idler sets.

Assuming the LRR testing machine will be working under industrial atmospheres with moderate sulphur dioxide pollution in a coastal area with low salinity, corrosivity protection for a C3 environment is adequate which cathodic protection, galvanizing and painting are able to provide.

\subsection{Material selection and corrosivity protection}

This section provides comparison and justification for of the materials selected to construct the components of the LRR testing machine. Decision matrices have been utilized to justify the material selection for these components. Selection of the material to be used for the structural supports requires consideration for mechanical properties including strength, as well as cost, machinability and size availability. For this purpose, according to materials listed in Table 1, a decision matrix was generated in Table 2.

From the decision matrix, it was found that the most suitable material for the structural supports is 300 XLERPLATE due to its cost, ease of manufacturing and strength.
Although structural steel has exceptional physical and mechanical characteristics, due to its nature, it tends to react with oxygen and water present in the air to form a more stable compound called ferrous oxide, this natural reaction process is called corrosion or oxidation of the metal, and for this reason, protection from this corrosion is an important factor in the design of the system. Metal corrosion can be managed, slowed or even stopped by using the proper techniques. As shown in Table 3, the corrosivity of certain atmospheres has been classified and standardized into 5 levels by the International Organization for Standardization (ISO), in order of increasing corrosivity. It is important to know the corrosivity level of the environment before doing any corrosion protection to find a correct and suitable anti-corrosion solution.

Table 1 Considered materials for structural support [7]

\begin{tabular}{|l|l|l|}
\hline Material & Description & Typical Uses \\
\hline G450 & $\begin{array}{l}\text { Cold-rolled, high } \\
\text { strength, low alloy } \\
\text { steel }\end{array}$ & $\begin{array}{l}\text { Roll-formed sections for } \\
\text { structural applications }\end{array}$ \\
\hline CM350-G & $\begin{array}{l}\text { High strength } \\
\text { structural steel plate }\end{array}$ & Structural sections \\
\hline 300 & $\begin{array}{l}\text { High strength } \\
\text { Xtructural steel plate }\end{array}$ & $\begin{array}{l}\text { Structural members and } \\
\text { general fabrication }\end{array}$ \\
\hline 350 & $\begin{array}{l}\text { Cold-rolled, high } \\
\text { strength, low alloy } \\
\text { XLERPLATE }\end{array}$ & $\begin{array}{l}\text { Structural members and } \\
\text { general fabrication }\end{array}$ \\
\hline
\end{tabular}

Table 2 Decision matrix for structural material selection

\begin{tabular}{|c|c|c|c|c|c|c|}
\hline $\begin{array}{c}\text { Proper } \\
\text { ties }\end{array}$ & $\begin{array}{c}\text { Mecha } \\
\text { nical } \\
\text { Strengt } \\
\mathrm{h}\end{array}$ & $\begin{array}{c}\text { Co } \\
\text { st }\end{array}$ & $\begin{array}{c}\text { Ease of } \\
\text { Manufact } \\
\text { uring }\end{array}$ & $\begin{array}{c}\text { Corros } \\
\text { ion } \\
\text { Resist } \\
\text { ance }\end{array}$ & $\begin{array}{c}\text { Tot } \\
\text { al }\end{array}$ \\
\hline $\begin{array}{c}\text { Weigh } \\
\text { ting } \\
\text { coeffic } \\
\text { ient }\end{array}$ & & $\mathrm{X} 3$ & $\mathrm{X} 3$ & $\mathrm{X} 3$ & $\mathrm{X} 2$ & \\
\hline $\begin{array}{c}\text { Materi } \\
\text { al }\end{array}$ & G450 & 5 & 2 & 3 & 4 & 38 \\
\cline { 2 - 6 } & CM350-G & 4 & 2 & 3 & 4 & 35 \\
\cline { 2 - 6 } & $\begin{array}{c}300 \\
\text { XLPERP } \\
\text { LATE }\end{array}$ & 3 & 5 & 4 & 2 & 40 \\
\cline { 2 - 6 } & $\begin{array}{c}350 \\
\text { XLERPL } \\
\text { ATE }\end{array}$ & 4 & 3 & 4 & 2 & 37 \\
\hline
\end{tabular}

Assuming the LRR testing machine will be working under industrial atmospheres with moderate sulphur dioxide pollution in a coastal area with low salinity, corrosivity protection for a $\mathrm{C} 3$ environment is adequate, which cathodic protection, galvanizing and painting are able to provide.

The cathodic protection can provide strong corrosion resistance to the protected metal, as its applications are specially designed for C5M marine usage. However, this also comes with higher cost of installation by fully trained personnel, constant maintenance and the necessity for an external power source which comes with extra electrical costs. Because of this, cathodic protection will not be considered as a corrosion protection option. 
A COMPACT AND PORTABLE DESIGN DEVELOPMENT OF A LOW ROLLING RESISTANCE TEST RIG

Greg Wheatley; Ashley Rains; Mohammad Zaeimi

Table 3 Atmospheric corrosivity categories and examples of typical environments [8]

\begin{tabular}{|c|c|c|c|}
\hline $\begin{array}{c}\text { Corrosivity } \\
\text { category }\end{array}$ & $\begin{array}{c}\text { Low- carbon } \\
\text { steel Thickness } \\
\text { loss }(\mu m)\end{array}$ & Exterior & Interior \\
\hline $\begin{array}{c}\mathrm{Cl} \text { (very } \\
\text { low) }\end{array}$ & $t_{l}<1.3$ & - & $\begin{array}{c}\text { Heated } \\
\text { buildings with } \\
\text { clean } \\
\text { atmospheres, } \\
\text { e.g. offices, } \\
\text { shops, schools, } \\
\text { hotels }\end{array}$ \\
\hline C2 (low) & $1.3<t_{l}<25$ & $\begin{array}{c}\text { Atmospheres } \\
\text { with low level } \\
\text { of pollution: } \\
\text { mostly rural } \\
\text { areas }\end{array}$ & $\begin{array}{c}\text { Unheated } \\
\text { buildings where } \\
\text { condensation } \\
\text { can occur, e.g. } \\
\text { depots, sports } \\
\text { halls }\end{array}$ \\
\hline $\begin{array}{c}\mathrm{C} 3 \\
\text { (medium) }\end{array}$ & $25<t_{l}<50$ & $\begin{array}{c}\text { Urban and } \\
\text { industrial } \\
\text { atmospheres, } \\
\text { moderate } \\
\text { sulphur } \\
\text { dioxide } \\
\text { pollution; } \\
\text { coastal area } \\
\text { with low } \\
\text { salinity } \\
\end{array}$ & $\begin{array}{c}\text { Production } \\
\text { rooms with high } \\
\text { humidity and } \\
\text { some air } \\
\text { pollution, e.g. } \\
\text { food processing } \\
\text { plants, } \\
\text { laundries, } \\
\text { breweries, } \\
\text { dairies }\end{array}$ \\
\hline C4 (high) & $50<t_{l}<80$ & $\begin{array}{l}\text { Industrial areas } \\
\text { and coastal } \\
\text { areas with } \\
\text { moderate } \\
\text { salinity }\end{array}$ & $\begin{array}{l}\text { Chemical } \\
\text { plants, } \\
\text { swimming } \\
\text { pools, coastal } \\
\text { ship and } \\
\text { boatyards }\end{array}$ \\
\hline $\begin{array}{c}\text { C5I } \\
\text { (Industrial } \\
\text { very high) }\end{array}$ & $80<t_{l}<200$ & $\begin{array}{l}\text { Industrial areas } \\
\text { with high } \\
\text { humidity and } \\
\text { aggressive } \\
\text { atmosphere } \\
\text { and coastal } \\
\text { areas with high } \\
\text { salinity }\end{array}$ & $\begin{array}{l}\text { Buildings or } \\
\text { areas with } \\
\text { almost } \\
\text { permanent } \\
\text { condensation } \\
\text { and high } \\
\text { pollution }\end{array}$ \\
\hline $\begin{array}{c}\text { C5M } \\
\text { (Marine } \\
\text { extreme) }\end{array}$ & $\begin{array}{l}200<t_{l} \\
<700\end{array}$ & $\begin{array}{l}\text { Offshore areas } \\
\text { with high } \\
\text { salinity and } \\
\text { industrial areas } \\
\text { with extreme } \\
\text { humidity and } \\
\text { aggressive } \\
\text { atmosphere } \\
\text { and sub- } \\
\text { tropical and } \\
\text { tropical } \\
\text { atmospheres }\end{array}$ & $\begin{array}{l}\text { Industrial areas } \\
\text { with extreme } \\
\text { humidity and } \\
\text { aggressive } \\
\text { atmosphere }\end{array}$ \\
\hline
\end{tabular}

Galvanization has relatively strong corrosion protection with much lower cost and maintenance requirements compared to the cathodic protection. However, certain coating techniques and equipment is required for this which can be achieved in two ways, hot dipping and thermal spraying. The hot dipping method is needed to be done in the factory, which is inconvenient for onsite installation. To complete onsite the thermal spray method should be used, however this requires specific equipment and technicians. For these reasons, galvanization will also not be considered.
Painting is a widely used corrosion protection method for medium to low corrosivity environments due to its ease of application and maintenance, and much lower cost compared to the other two methods. Painting requires little to no technical expertise whilst still being able to provide the benefits of a corrosion protection coating. Furthermore, touch-up painting can be included as part of the regular maintenance schedule to continually fix abrasions in the coating, something that is not as simple with the other methods. Because of this, it can be concluded that the anticorrosion solution for the system should be painting which is suitable to cover corrosivity level of C3 with minimum cost and maintenance requirements.

\subsection{Relevant standards}

To ensure the quality of the system, all work must be in accordance with relevant Australian Standards and professional expectations. Table 4 below lists key standards when contemplating a design for any type of conveyor. These standards ensure products, services and systems are safe, reliable and consistently perform as intended; without them, operational and safety requirements will not be met from the table below, it can be seen that AS, NZS and DIN standards are used throughout.

Table 4 List of Australian Standards pertaining to conveyor belts [9]

\begin{tabular}{|c|c|}
\hline Standard Number & Standard \\
\hline AS 1755-2000 & Conveyors Safety Requirements \\
\hline AS 1334. 13:2017 & $\begin{array}{c}\text { Methods of testing conveyor and } \\
\text { elevator belting, determination of } \\
\text { indentation rolling resistance of } \\
\text { conveyor belting. }\end{array}$ \\
\hline AS/NZS & $\begin{array}{c}\text { Safety of machinery Conveyors - } \\
\text { General requirements }\end{array}$ \\
\hline AS 4035-1992(R016) & $\begin{array}{c}\text { Conveyor and elevator belting - } \\
\text { Glossary of terms }\end{array}$ \\
\hline AS 4024.3610 & $\begin{array}{c}\text { Safety of Machinery Conveyors: } \\
\text { General Requirements }\end{array}$ \\
\hline AS 4024.3611 & Conveyors: Belt conveyors for bulk \\
& materials handling \\
\hline AS 4100 & Steel Structures \\
\hline AS 3990-1996(R2016) & Mechanical Equipment \\
\hline DIN 22101 & $\begin{array}{c}\text { Continuous conveyors - Belt conveyors } \\
\text { for loose bulk materials }\end{array}$ \\
\hline
\end{tabular}

\subsection{Supporting structural}

The design of the supporting structure must be capable of supporting the testing assembly during operation with the combined weight of itself, the idlers, the belt and the LRR testing frames. The structural design consists of a simple box frame of universal columns and beams. The loading on the sections must be analyzed using AS 41001998 and other methodologies such as ANSYS modelling to ensure that the load of the fully tensioned belt can be supported through each beam and footing. Torsional and stiffness analysis of the structure will indicate if cross members and stiffeners are required. 


\subsection{Installation}

The planned LRR replacement or upgrade is to be placed indoors for a table top size testing machine. This presents a challenge, as the area size and accessibility were unknown, and restricted access for large machinery is a likely problem. The proximity of the surrounding will restrict to the height and footprint of the design. Therefore, a design that can be constructed on site is preferable to remove most of the issues that would be encountered with the unknown destination. A design is also needed to take into consideration of safety as the testing machine will need to be surrounded by a safety guard.

\section{Results and Discussion}

In order to obtain the best possible design for the LRR testing machine, a concept development process was undertaken. In this process, components including the tensioning method, frame size weight and the roller size and design were considered. Influence on the designs were taken from Australian Standards. The final design incorporated as many positive aspects that are reasonably possible when maintainability, constructability, practicality and safety are considered. Further justification of the designs is achieved through FEA.

Note that, the existing machine utilizes two $1000 \mathrm{~mm}$ diameter pulleys and accepts pre-spliced endless belt samples $29 \mathrm{~m}$ in length and up to $600 \mathrm{~mm}$ wide, with 400 $\mathrm{mm}$ wide belts preferable to simulate higher loading per unit width of belt. The maximum load that can be applied to the test idler roll is $800 \mathrm{~kg}$ which allows a maximum belt load of $19.6 \mathrm{kN} / \mathrm{m}$ for a $400 \mathrm{~mm}$ wide belt [2].

\subsection{First concept}

The first concept was that developed by an existing machine which is approximately $13 \mathrm{~m}$ long and $100 \mathrm{~T}$ in weight. With large $1 \mathrm{~m}$ rollers and the measurement frame being approximately $2 \mathrm{~m} \times 1 \mathrm{~m} \times 1.25 \mathrm{~m}$ a large reduction in size is needed. A Model has been developed using SolidWorks 2017 (see Figure 2) and FEA was conducted using ANSYS Workbench 18.2 to analyses the deformation, stress and strain of each part of the LRR machine. This model was designed with the supporting structure made from structural steel that can be easily acquired from most metal distributors as they are common sizes making access to materials much easier. The testing was completed under the assumption that the force acting upon the structure was under a static load.

The stress and strain distribution are obtained through the structural analysis to check different parts and find out which one needs to be modified. It has shown that the LRR testing machine is more than capable of withstanding the forces acting upon it from the tension of the belt with a maximum Von-Mises stress of 86.6 MPa (see Figure 3(b)), a maximum Von-Mises strain 0.0004 (see figure 3(e)) and a maximum deformation of $0.00048 \mathrm{~m}$. Therefor the material used in construction is well within a high factor of safety for its use.

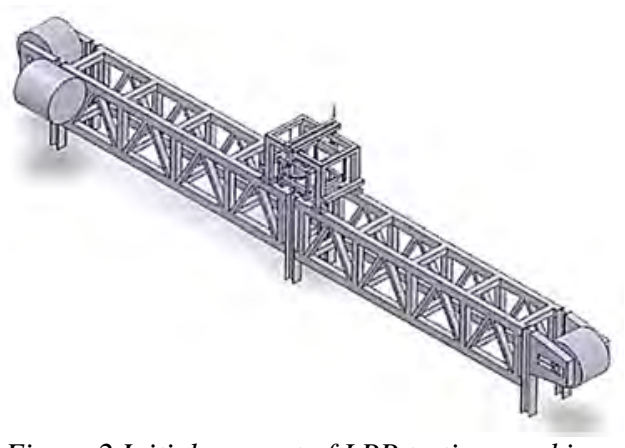

Figure 2 Initial concept of LRR testing machine

The construction of the LRR testing machine is of segmented design with 6 main $U$ beams bolted into the floor where the 2 large $6 \mathrm{~m}$ supporting structures are connected. Once the supporting structure is connected the two large $1 \mathrm{~m}$ rollers and outer and inner measuring frame are connected and indentation roller can then be attached. All sections are bolted together making transportation easier. However, as the total machine is extremely heavy a crane is needed to place the parts in place for construction of the testing rig.

The within the connection between the inner and outer frames for the measurement roller consists of two main threaded rods which can be adjusted to raise or lower the measurement roller changing the pressure upon the belt itself. This pressure is measure using a knife edge support between the inner supporting frame and the measurement roller. This knife edge is 60 degrees to 30 degrees match giving the roller a movement of 15 degrees in each direction making the friction force negligible. A torque sensor is connected to the end of the of the measurement rollers section of the knife edge connection reading the force applied to the roller under operation. There are both horizontal and vertical load cells attached between the inner and outer measurement frames to measure the force applied to both the belt and measurement roller for precise calibration and result collection.

Variable hold down rollers are attached at either side of the measuring rollers position. The use of these hold down rollers is to level the belt coming into the measurement system as well as applying a variable load depending on the position of these rollers. There is a similar adjustment method used for the outer rollers, where the large $1 \mathrm{~m}$ diameter rollers are connected to a bearing attached to a block and then a threaded rod which can be adjusted to tension the belt or so that different sized belts can be used. 


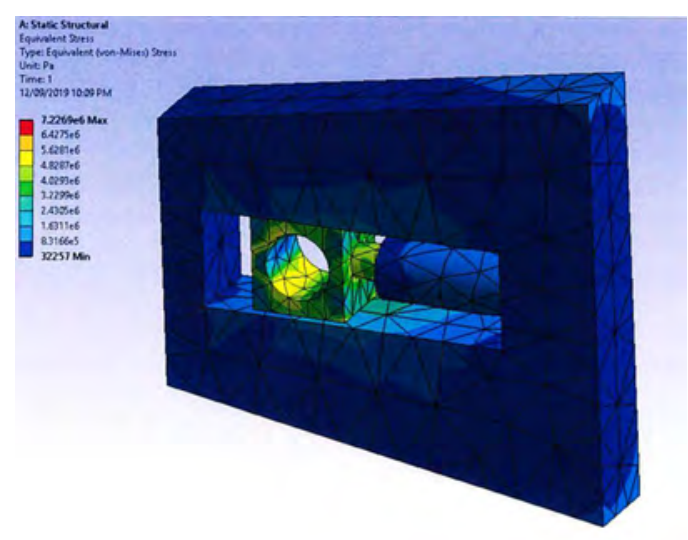

(a)

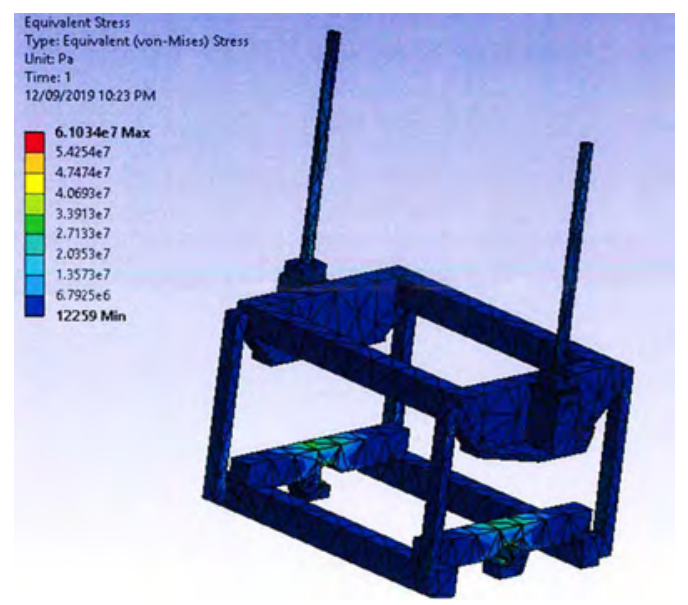

(c)

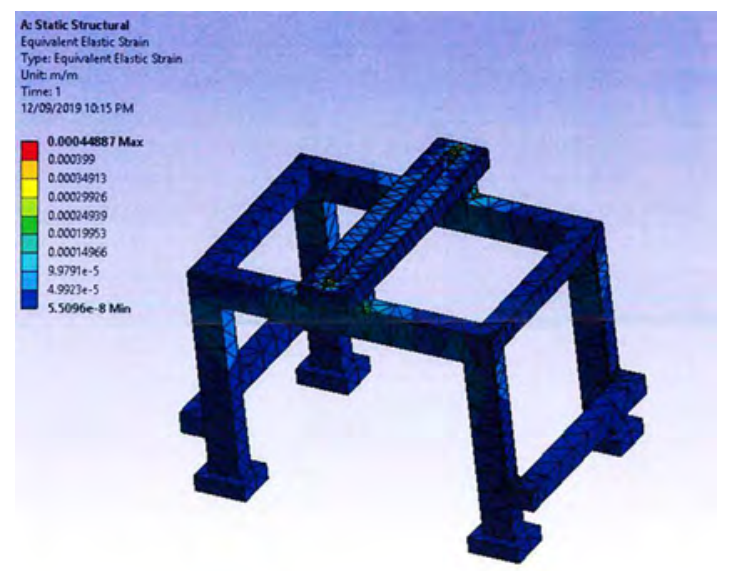

(e)

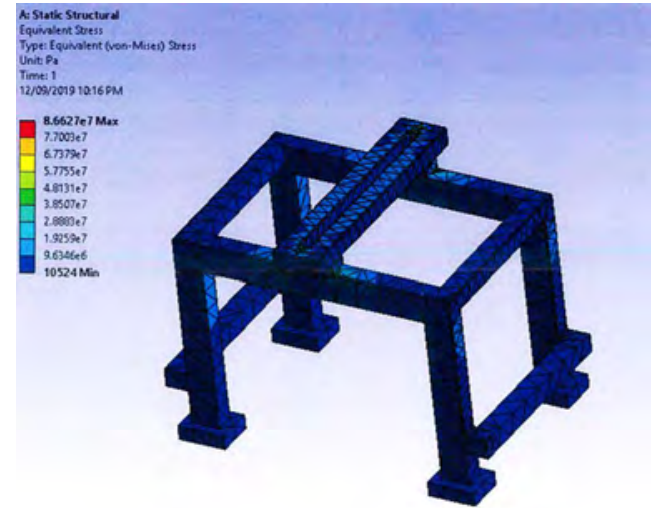

(b)

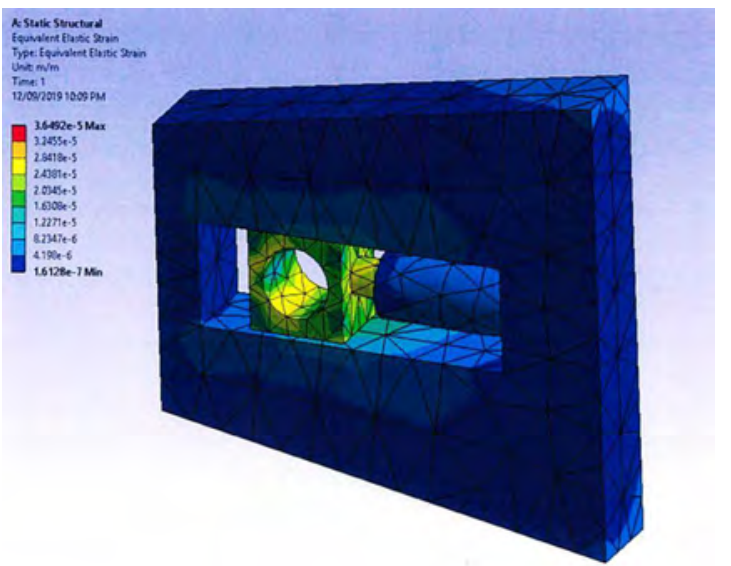

(d)

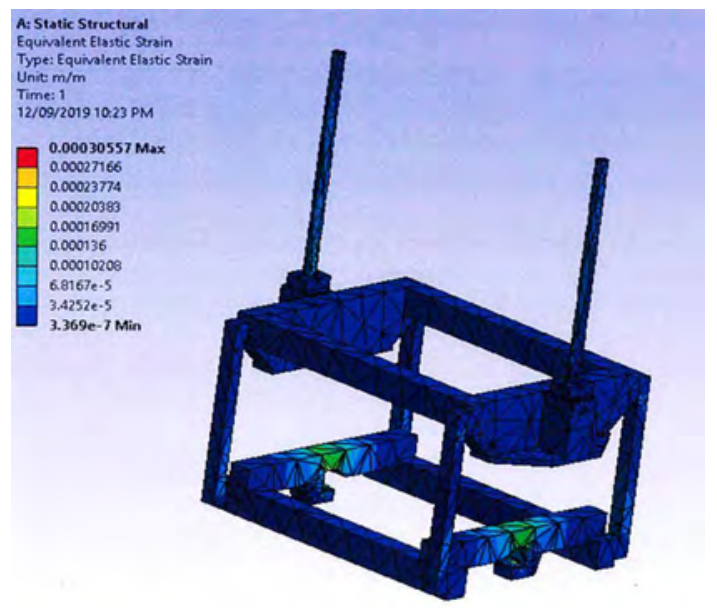

$(f)$

Figure 3 first design: (a) Tensioner stress (b) Outer measuring frame stress (c) Inner measuring frame stress (d) Tensioner strain (e) Outer measuring frame strain (f) Inner measuring frame strain

The LRR testing machine over all is a very well designed for its use of testing belts of different sizes under different conditions. Because of this downscaling the machine will be easy as nothing needs to be changed, however, a few adjustments may be implemented.
Replacing the knife edge system with a torque rod sensor as well as putting sliding rails on the top of the supporting frame to move the variable hold down rollers, as the current system is moved by unbolting moving and re bolting the rollers. Finally having the motor and its roller fixed in place 
at one end and having the opposing end be the only one to have a tensioner assembly to decrease parts and increase stability of the machine.

\subsection{Second concept}

The second concept is almost the exact same as the first concept as the first concept has all the functionality needed to complete the task but it has been reduced in size considerably (see Figure 4).

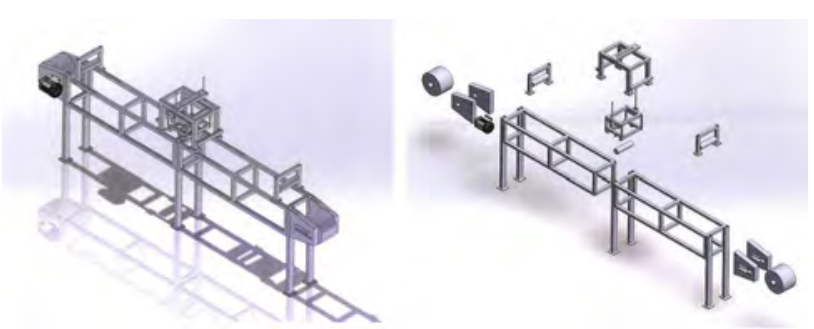

Figure 4 Final design of LRR testing machine

Table 5 Pulley specifications

\begin{tabular}{cc}
\hline Parameter & \\
\hline Minimum pulley diameter & $108 \mathrm{~mm}$ \\
Pulley face width & $200 \mathrm{~mm}$ \\
Clearance for the pulley face to belt & $25 \mathrm{~mm}$ \\
edge & $17.9 \mathrm{~mm}$ \\
Shell thickness & $90 \mathrm{~mm}$ \\
Shaft diameter &
\end{tabular}

For this design the improvements have been made from the initial design. The first improvement was that of the variable hold down rollers are more mobile with a runner system, the tensioning method is that where the motor pulley is fixed at one end and the opposing side has a screw tensioner that can be adjusted to the correct tension, the supporting frame has been simplified as its previous design was over engineered for its application and finally the pulleys were mathematically analyzed to determine their design. Pulley parameters are listed in Table 5 based on the calculations presented below. Figure 5 specified pulley design parameters.

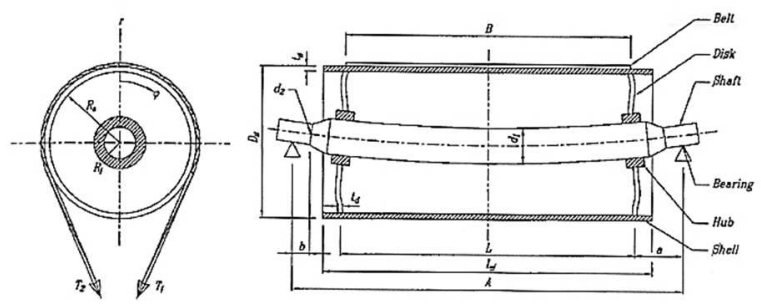

Figure 5 Pulley design parameters used in the LRR testing machine

In order to determine the minimum diameter $\left(D_{s}\right)$ for a pulley the following equations is used:

$$
D_{s}=t_{c s} C_{c s}
$$

Where $t_{c s}$ is the belt carcass thickness in mm which for the given belt is $4.6 \mathrm{~mm}$ and $C_{c s}$ is a factor dependent on the carcass material which for the given belt is 108 . Therefore, the minimum diameter for the drive and head pulley should be no less than $300 \mathrm{~mm}$. The minimum pulley face width is dependent on the belt width, with the other appropriate dimensions. As the maximum belt width is $150 \mathrm{~mm}$ the face width needs to be $200 \mathrm{~mm}$, the clearance for the pulley face to belt edge should be $25 \mathrm{~mm}$. The locking elements, bearings and plumber blocks are offthe-shelf products which are manufactured in standard sizes and for certain limitations, hence, the design of the pulleys and shafts will take this into consideration. To determine the shell thickness two checks must first be made. The first is a stress check which is done using the following equation:

$$
\begin{aligned}
t_{s 1} & =\sqrt{\frac{0.127 k_{s} p_{1} D_{s}}{F_{r}}} \\
p_{1} & =\frac{T_{\text {max }}}{B}
\end{aligned}
$$

Where $k_{s}$ is a safety coefficient which is assumed to be $1.2, T_{\text {max }}$ is calculated to be the carrier side tension for an overloaded belt equal to $58.4 \mathrm{kN}$ and $\mathrm{B}$ is the belt width of $150 \mathrm{~mm}, D_{s}$ is the pulley diameter previously calculated and $F_{r}$ is endurance limit of the shell material equal to 55 MPa for 250 Grade carbon steel. Therefore, the thickness for the drive and head pulley should be $17.9 \mathrm{~mm}$. The second check is a buckling check. This is given by:

$$
\begin{aligned}
& t_{s 2}=\sqrt[3]{\frac{\left(1-v^{2}\right) p_{2} D_{s}^{3}}{2 E}} \\
& p_{1}=\frac{2 T_{\max }}{D_{s} B}
\end{aligned}
$$

Where $v$ is Poisson's ratio which is 0.3 for steel, $E$ is Young's modulus which is $210 \mathrm{GPa}$ for steel. This gives a drive and head pulley thickness of $5.33 \mathrm{~mm}$. The greater of these two thicknesses is to be selected. Therefore, the wall thickness of the drive and head pulley is equal to $17.9 \mathrm{~mm}$ and should therefore be no less than $18 \mathrm{~mm}$ when constructed. To determine the shaft diameter, torque and bending moment need to be first calculated. Torque is calculated using:

$$
T_{q}=T_{e} \frac{D_{s}}{2} 10^{-3}
$$

Where $T_{e}$ is the effective tension in $\mathrm{N}$ which is equal to $58.4 \mathrm{kN}$ for the overloaded case. Torque will be equal to $8.76 \mathrm{kNm}$. Bending moment is calculated by: 


$$
M_{b}=\left(\frac{T_{\max }}{2}\right) \frac{(A-l)}{2}
$$

Where $T_{\max }$ is the pulley total load, $A$ is the distance between bearing centres which is equal to $0.28 \mathrm{~m}$ and $l$ is the distance between disc plates which is equal to $0.175 \mathrm{~m}$. Therefore, bending moment is $1.53 \mathrm{kNm}$. Finally, to determine the diameter the following equation is used:

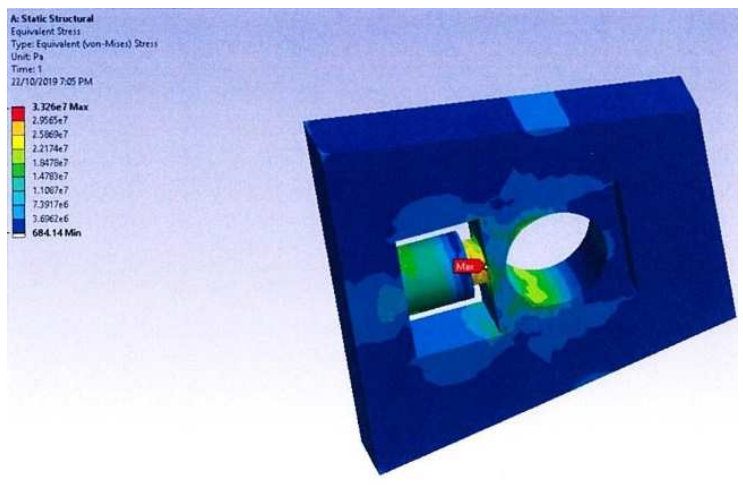

(a)

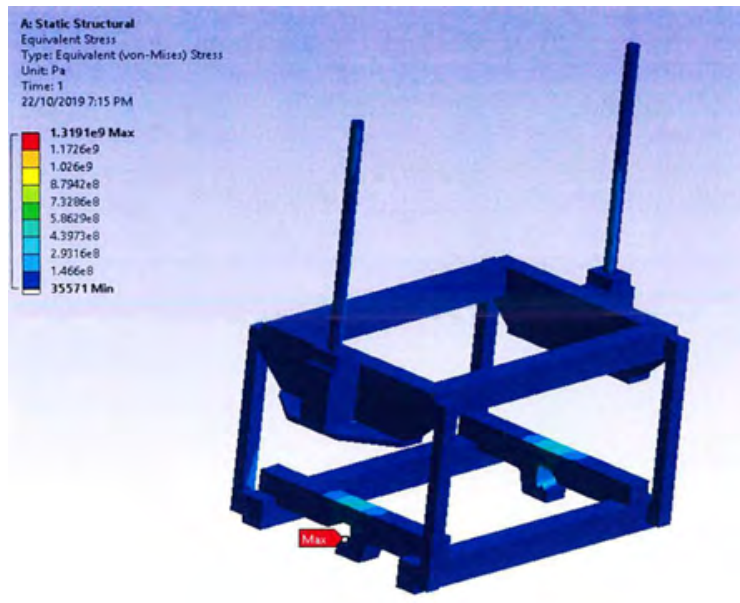

(c)

$$
d_{s}=\left[\frac{10^{4} K_{s} K}{F_{r}} \sqrt{M_{b}^{2}+0.75 T_{q}^{2}}\right]
$$

Where $K$ is a stress rising factor which for this given situation is $3, F_{r}$ is the endurance limit of the shaft material which is $630 \mathrm{MPa}$ for 1060 steel and $K_{s}$ is a size factor which for the expected shaft diameter is 1.71 . Therefore, a shaft diameter of $90 \mathrm{~mm}$ is to be used.

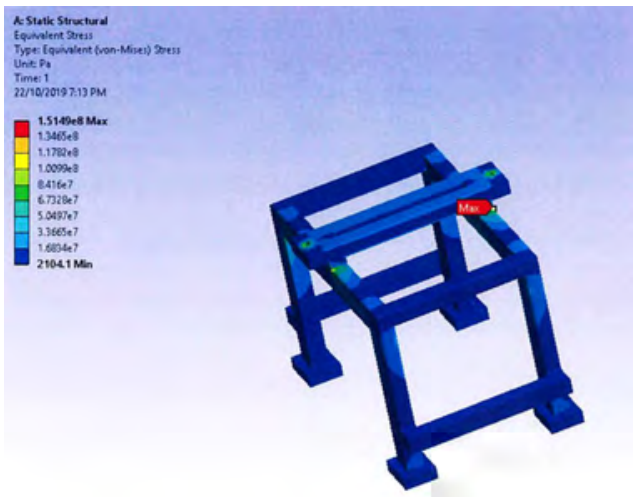

(b)

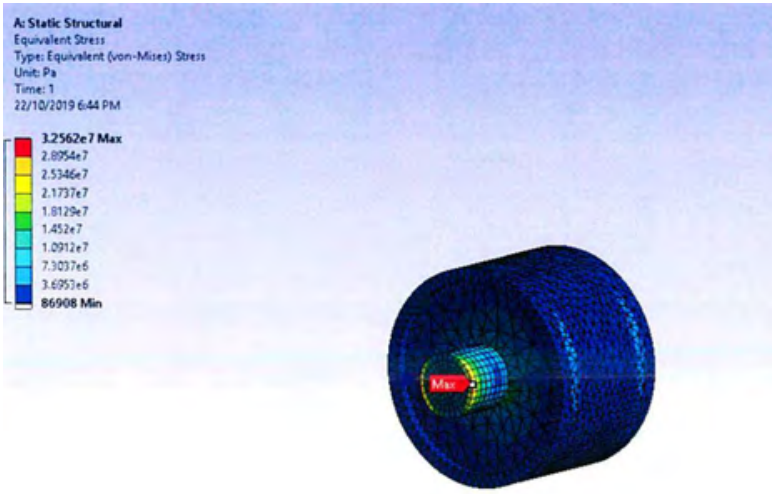

(d)

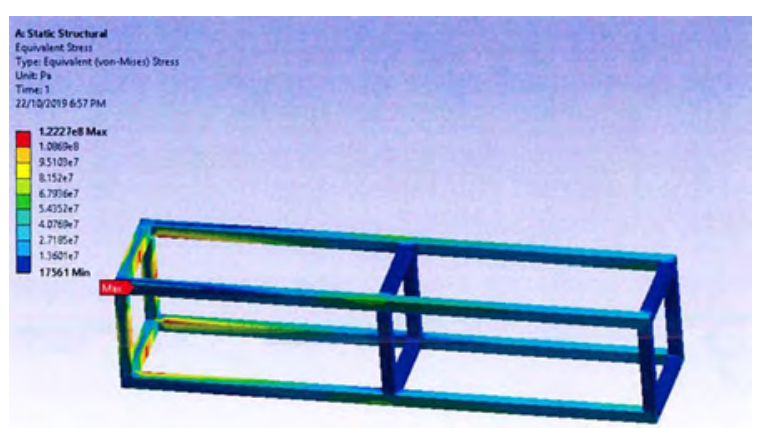

(e)

Figure 6 final design stress distribution: (a) Tensioner (b) Outer measuring frame (c) Inner measuring frame (d) pulley $(e)$ frame 
The supporting structure was designed from available sized steel that can be bought from steel wholesalers. For the FEA analysis it was assumed that the machine is under static load while it is being operated. From the 300 XLERPLATE steel being used has a yield strength of 320 $\mathrm{MPa}$ and a tensile strength of $430 \mathrm{MPa}$, it is clearly shown that the final design can withstand the forces acting upon it when under operation. As the maximum stress acting upon on the outer measurement frame being $151.5 \mathrm{MPa}$ (see Figure 6(b)) making the lowest factor of safety being 2.11, a maximum strain of 0.0066 and a maximum deformation $0.0022151 \mathrm{~m}$ showing that for the chosen material and design the LRR testing machine will be to standard.

The final design having two main $1.5 \mathrm{~m}$ long frame sections with 6 legs that can be segmented so that construction and transport can be completed easily. The new design has two $300 \mathrm{~mm}$ diameter pulleys at either end, the motor pulley is fixed which will be attached directly to the outside of the frame with the other side having the tensioner assembly attached. The tensioner assembly is the same as that of the previous design however it has been downsized to accommodate the new roller and belt forces. Variable hold down rollers are attached at either side of the measuring rollers position. The new design has rails for the variable hold down rollers to slide along so that they can be changed easily and accurately. The final LRR testing machine will be able to handle the forces acting upon it from that of the belt while maintaining its long life.

\subsection{Technical specifications and design compliance}

This section details the mechanical analysis process carried out to assess the specifications and performance of the currently existing system operating in Newcastle, and the new downscaled version. It contains the development of critical load cases with which calculations can be carried out to find necessary parameters, such as belt tensions (carry side, return side and effective), drive power, as shown in figure 7 , and mass flow rate for various materials.

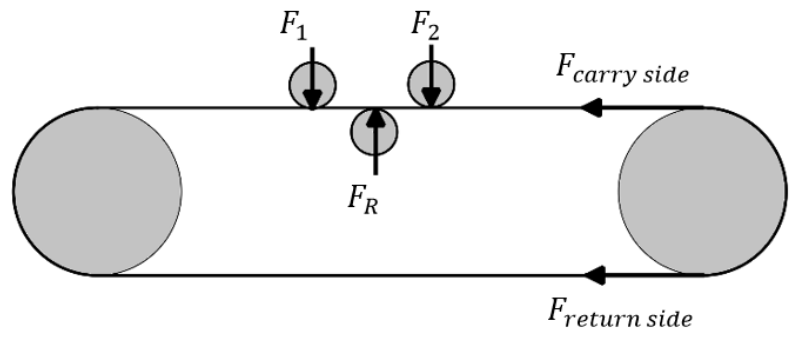

Figure 7 General load case free body diagram

Results are obtained using the following equations from DIN 22101-2011 and proposed in Table 5 with the definition of all parameters:
Carry side tension

$F_{T 1}=\frac{g\left(m_{L}^{\prime}+m_{g}^{\prime}\right) \cdot l_{r}}{8 h_{r e l}}$

Where

$m_{L}^{\prime}=\frac{F_{\max }}{b}$

Return side tension

$\frac{F_{T 1}}{F_{T 2}}=e^{\mu \phi}$

Effective tension

$F_{e}=F_{T 2}-F_{T 1}$

Drive power

$P=F_{e} \cdot v$

Mass flow rate

$\dot{m}_{s}$

$=\rho_{b} \cdot\left(0.5 \times b^{2} \tan (\delta)\right) \cdot v \cdot k_{s}$

Knowing these parameters allows the designer to make informed design decisions especially in terms of scaling of the machine. The main advantage of this analysis process is its ease of application to any load case scenario. Any load case can be very simply analyzed, only requiring the altering of key variables such as line load. Utilizing this universal approach is also advantageous in that it allows for easy comparison between any load cases of interest, such as the maximum versus operating parameters, or the original rig's maximums versus that of the downscaled version. As shown in Table 7, two conditions were considered to investigate their performance. The initial analysis considers the "worst-case scenario" loading condition, while the second one is a more reasonable "standard operation" case. Parameters for these cases can be drawn directly from ref [3]. It should be noted that the maximum load capable of being applied by the test rig is determined with respect to both the belt width and belt speed. Iron ore was considered for the mass flow rate calculation due to it having the highest bulk density as shown in Tables 6-8 and Figure 8. Steady-state operating conditions and rigid body belt due to the short belt length are assumed in the calculation process. Moreover, line load resulting from the conveyor is considered to zero.

Physical specifications were downscaled drastically from a machine approximately 100 tonnes in weight and $13 \mathrm{~m}$ or more in length (hence requiring extensive supporting infrastructure- and subsequent effort and cost 
for installation or moving). The new machine as currently designed will easily fit within a bounding box of approximately $3 \mathrm{~m}$ (length) $\times 2 \mathrm{~m}$ (height) $\times 1.5 \mathrm{~m}$ (width)

The existing machine could operate at a maximum belt velocity of $10 \mathrm{~m} / \mathrm{s}$ (standard operation was approximately
$4 \mathrm{~m} / \mathrm{s}$ ), and the new design is intended to be able to match that velocity specification. As far as belt options, the current machine can test belts up to $600 \mathrm{~mm}$ in width, as opposed to the new design which can test up to $150 \mathrm{~mm}$.

\begin{tabular}{|c|c|c|c|c|}
\hline Material & $\begin{array}{c}\text { Bulk density } \\
\text { (tonnes/m*) }\end{array}$ & Angle of repose & $\begin{array}{l}\text { Recommended max } \\
\text { angle of inclination }\end{array}$ & $\begin{array}{c}\text { Surcharge } \\
\text { angle }\end{array}$ \\
\hline Alumina & $0.8-1.08$ & $22^{\circ}$ & $12^{\circ}$ & $10^{\circ}$ \\
\hline Ammonium chloride & $0.72-0.83$ & - & $10^{\circ}$ & $10^{\circ}$ \\
\hline Ammonium nitrate & 0.72 & - & $23^{\circ}$ & $25^{\circ}$ \\
\hline Ashes (coal) - dry & $0.56-0.64$ & $45^{\circ}$ & $20^{\circ}$ & $30^{\circ}$ \\
\hline Ashes (coal) - wet & $0.72-0.80$ & $45^{\circ}$ & $20^{\circ}$ & $30^{\circ}$ \\
\hline Ashes (coal) - fry & $0.5-0.8$ & $42^{\circ}$ & 220 & $30^{\circ}$ \\
\hline Barley & 0.61 & $23^{\circ}$ & $12^{\circ}$ & $5-10^{\circ}$ \\
\hline Barytes (fine) & $1.8-2.0$ & $35^{\circ}$ & $15^{\circ}$ & $10^{\circ}$ \\
\hline Bauxite(granular) & $1.20-1.36$ & $30^{\circ}$ & $20^{\circ}$ & $20^{\circ}$ \\
\hline Cement & $1.20-1.36$ & $30^{\circ}$ & $15-18^{\circ}$ & $10-20^{\circ} *$ \\
\hline Chalk (fine) & $1.0-1.2$ & $42^{\prime \prime}$ & $25^{\circ}$ & $25^{\circ}$ \\
\hline Chalk (lumpy) & $1.2-1.4$ & $42^{\circ}$ & $! 5^{\circ}$ & $10^{\circ}$ \\
\hline Clay (dry fine) & $1.6-1.9$ & $35^{\circ}$ & $20 "$ & $22^{\circ}$ \\
\hline Coal (bituminous) & $0.72-0.88$ & $35^{\circ}$ & $18^{\circ}$ & $18^{\circ}$ \\
\hline Coke & $0.4-0.5$ & $38^{\circ}$ & $18^{\circ}$ & $25^{\circ}$ \\
\hline Copper ore & $1.92-2.56$ & $38^{\circ}$ & $20^{\circ}$ & $25^{\circ}$ \\
\hline Iron ore & $2.08-2.88$ & $35^{\circ}$ & $18^{\circ}$ & $20^{\circ}$ \\
\hline Kaolin clay & 1 & $35^{\circ}$ & $19^{\circ}$ & $20^{\circ}$ \\
\hline Limestone & $1.44-1.52$ & $38^{\circ}$ & $18^{\circ}$ & $25^{\circ}$ \\
\hline Phosphate rock (broken dry) & $1.2-1.3$ & $28^{\circ}$ & $14^{\circ}$ & $10^{\circ}$ \\
\hline Pyrites (lumpy) & $2.1-2.3$ & $35^{\circ}$ & $16^{\circ}$ & $20^{\circ}$ \\
\hline Sand-dry & $1.4-1.60$ & $35^{\circ}$ & $16^{\circ}$ & $20^{\circ}$ \\
\hline Sand-foundry & $1.3-1.4$ & - & $24^{\circ}$ & $30^{\circ}$ \\
\hline Soda ash (light) & $0.35-0.55$ & $37^{\circ}$ & 220 & $25^{\circ}$ \\
\hline Sugar-raw & $0.88-1.04$ & $45^{\circ}$ & $18^{\circ}$ & $30^{\circ}$ \\
\hline Wheat & 0.77 & $28^{\circ}$ & 120 & $10^{\circ}$ \\
\hline Wood chips & $0.16-0.48$ & - & $27 "$ & $30^{\circ}$ \\
\hline
\end{tabular}

* Surcharge can be $0^{\circ}$ if cement is aerated and max. inclination could then be $5-10^{\circ}$ )

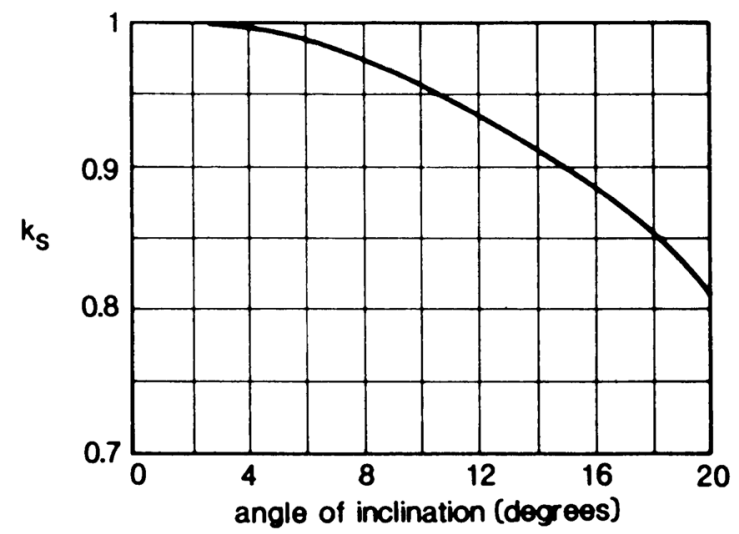

Figure 8 Slope factor $k_{s}$, for smooth (unpatterned) belts operating on a gradient [10]

$$
\sim 377 \sim
$$


A COMPACT AND PORTABLE DESIGN DEVELOPMENT OF A LOW ROLLING RESISTANCE TEST RIG

Greg Wheatley; Ashley Rains; Mohammad Zaeimi

Table 7 Recommended friction coefficients $\mu$ for the friction between belts with a rubber cover and pulley surfaces of different finishes [11]

\begin{tabular}{|c|c|c|c|c|}
\hline Operating condition & \multicolumn{3}{|c|}{ Friction coefficient for pulley surface $(\mu) *$} \\
\hline & $\begin{array}{c}\text { bright metal surface } \\
\text { (plain steel pulley) }\end{array}$ & $\begin{array}{c}\text { polyurethane lagging } \\
\text { (arrow pattern) }\end{array}$ & $\begin{array}{c}\text { rubber lagging } \\
\text { (arrow pattern) }\end{array}$ & $\begin{array}{c}\text { ceramic lagging with pores } \\
\text { (arrow pattern) }\end{array}$ \\
\hline Dry & $0.35-0.4$ & $0.35-0.4$ & $0.4-0.45$ & 0.35 \\
\hline Wet (clear water) & 0.1 & 0.35 & $0.4-0.45$ & $0.35-0.4$ \\
\hline Wet dirty (with mud and clay) & $0.05-0.1$ & 0.2 & $0.25-0.3$ & 0.35 \\
\hline
\end{tabular}

* For conveyor belts with a PVC cover approx. $10 \%$ smaller friction coefficients shall be assumed

Table 8 Performance comparison

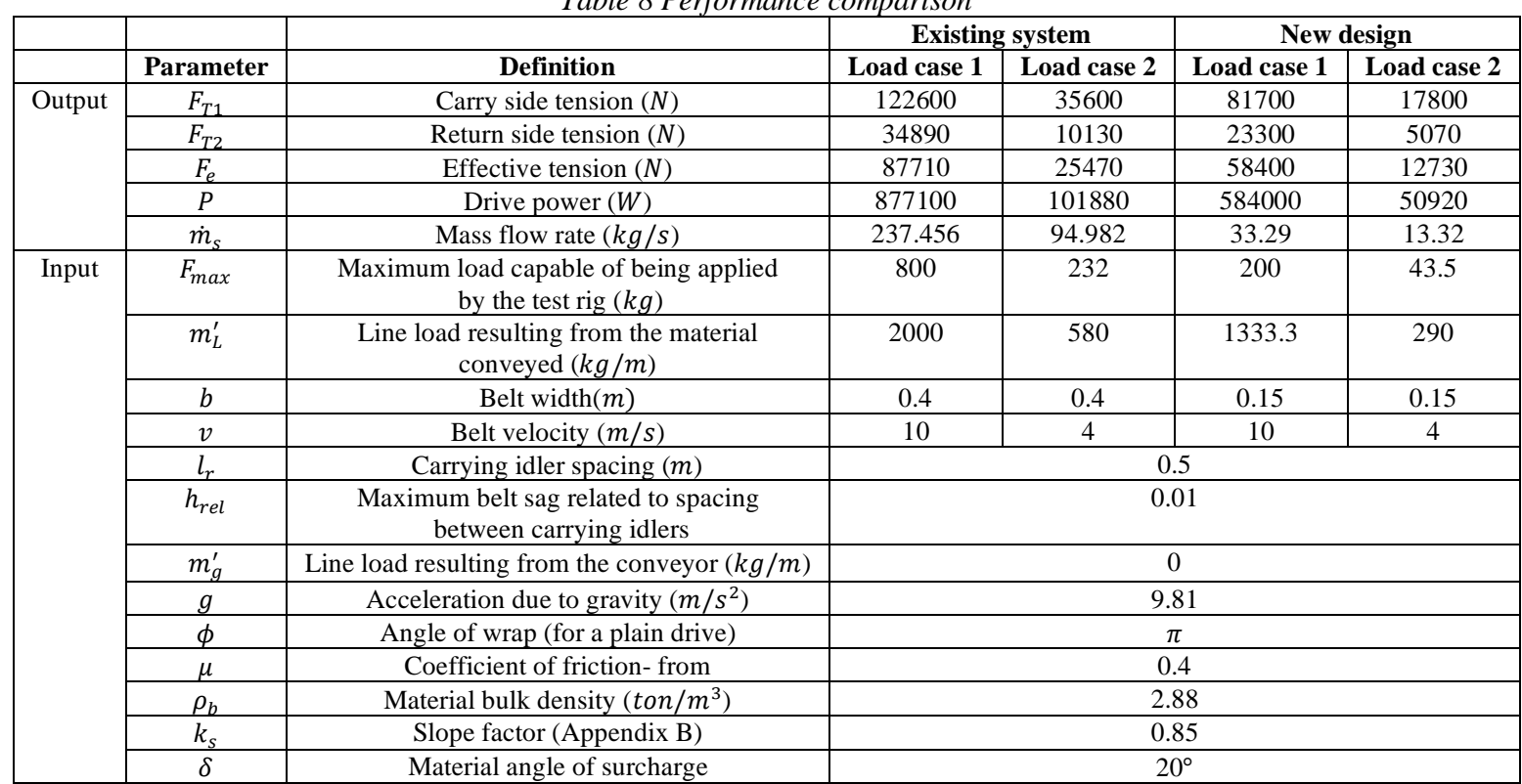

\section{Conclusion}

In this work, a concept development process is provided to design the components of a LRR testing machine. The final design is based on the improvement of the existing test rig since it has all requirements to complete the task but the new one has been reduced in size considerably. Decision matrices have been used to justify the material selection. Due to cost, ease of manufacturing and strength, 300 XLERPLATE is selected for the structural supports and painting is considered as a suitable anti-corrosion solution to cover corrosivity level of C3. To ensure the quality, the system is designed based on the related Australian Standards, and justification is achieved through finite element analysis by investigating the deformation, stress and strain of each part. Physical specifications of the first concept is downscaled drastically to a compact, portable and desktop-sized model. Furthermore, a few adjustments are carried out for the variable hold down rollers, the tensioning method, frame geometry and the roller size. Under distinct loading conditions, necessary parameters including belt tensions, drive power, mass flow rate are obtained to compare the performance of the currently existing system operating in Newcastle, and the new downscaled version.

\section{References}

[1] PRESTENBACH, M.: What are the functions of the conveyor belt?, [Online], Available: https://www.conbelt.com/what-are-the-functions-ofthe-conveyor-belt-2/ [23 Jul 2021], 2019.

[2] MUNZENBERGER, P., WHEELER, C.: Laboratory measurement of the indentation rolling resistance of conveyor belts, Measurement, Vol. 94, pp. 909-918, 2016. doi:10.1016/j.measurement.2016.08.030

[3] ROBINSON, P.W., WHEELER, C.A.: The indentation rolling resistance of spherically profiled idler rolls, International Journal of Mechanical Sciences, Vol. 106, pp. 363-371, 2016. doi:10.1016/j.ijmecsci.2015.12.001

[4] HAGAR, M., HINTZ, A.: The energy-saving design of belts for long conveyor systems, Bulk Solids Handling, Vol. 13, pp. 749-758, 1994.

[5] ZAHANG, Y.: Save energy by minimising belt rolling resistance, [Online], Available: https://www.processworldwide.com/conveyor-belts-save-energy-byminimising-belt-rolling-resistance-a-408877/ [23 Jul 2021], 2018.

[6] SPAANS, C.: The calculation of the main resistance of belt conveyors, Bulk Solids Handling, Vol. 11, pp. 809826, 1991. 
[7] Bluescope, Australian steel products, [Online], Available: https://www.bluescope.com/about-us/ourbusiness/australian-steel-products/ [23 Jul 2021], 2021.

[8] ISO, ISO12944-2: Paints and varnishes - corrosion protection of steel structures by protective paint systems - part 2: classification of environments, [Online], Available: https://www.iso.org/standard/648 34.html [23 Jul 2021], 2021.

[9] SAIGLOBAL, [Online], Available: https://www.saigl obal.com/en-gb/standards/ [23 Jul 2021], 2021.
[10] WOODCOCK, C.R., MASON, J.S.: Bulk Solids Handling: An Introduction to the Practice and Technology, $1^{\text {st }}$ ed., Springer, Netherlands, 1988.

[11] DIN, DIN2210: Continuous conveyors - belt conveyors for loose bulk materials - basis for calculation and dimensioning, [Online], Available: https://global.ihs.com/doc_detail.cfm?document_na me=DIN\%2022101\&item_s_key=00027970 [23 Jul 2021], 2011.

\section{Review process}

Single-blind peer review process. 